\title{
International recognition and human rights treaties
}

Ralph Wilde, UCL

published as Chapter 8 in Routledge Handbook of State Recognition (Gëzim Visoka, John Doyle, Edward Newman, eds., Routledge, 2019) (double blind peerreviewed), 99-108

PRE-PUBLICATION DRAFT, PLEASE CHECK AGAINST PUBLISHED VERSION

Abstract:

The chapter argues that international human rights treaties contain obligations with implications for the practice of recognition/non-recognition by states of other states and governments. It begins by explaining how international human rights treaty obligations relate to extraterritorial situations and how this might apply to the practice of recognition/non-recognition. It then explains how recognition/nonrecognition practice is understood in international law. Following this, the chapter addresses what human rights treaty standards would require of recognition/nonrecognition. Finally, consideration is given to the potential divergence in the human rights obligations of the recognizing/non-recognizing state, and the obligations of the object of that recognition/non-recognition.

\section{Contents}

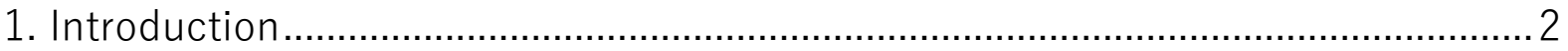

3. The territorial and extraterritorial application of human rights treaty obligations, and the 'effects' obligation in particular ......................................................................... 5

4. Applying human rights treaty law to recognition/non-recognition practice ........ 7

5. The role of recognition of states, governments, and state activities in international law

6. What human rights treaty law would require of recognition/non-recognition practice 
7. How would obligations be linked to those of the recognized/non-recognized entity?

8. Conclusion.

\section{Introduction}

The invocation of human rights considerations when states recognize or deny recognition to other states and governments in general, and particular activities performed by other states in particular, is a common, long-standing feature of international relations. This practice is often characterised by inconsistency, double-standards, mixed motives and bad faith. In international law, the issue of statehood, and the recognition of states and governments, is a matter of "customary international law." This is the area of international law derived from identifying a consistent practice between states, allied to evidence that the practice in question is understood by the states concerned to be not merely a matter of discretion but taking place on the basis of compulsion. Of necessity, discussing human rights and recognition/non-recognition by adopting this focus takes as its starting point the recognition/non-recognition practice of states. Working within this context, it is necessarily difficult to find sufficient evidence to meet the test for customary international law, at least as a matter of generality, bearing in mind the aforementioned inconsistency, double-standards, mixed motives, and bad faith. ${ }^{2}$

However, an important international legal development that has taken place since the turn of the millennium suggests a new avenue through which this enquiry could be pursued, through a different branch of international law than customary international law. This development is the acceptance that international human rights treaties include responsibility regarding extraterritorial 'effects', and apply to states when they act extraterritorially. ${ }^{3}$

For the first half-century into the lifespan of the foundational instrument of international human rights law, the Universal Declaration of Human Rights of 
1948 - the second half of the twentieth century - the question of whether and to what extent human rights treaty law, which followed from the Universal Declaration (itself not a treaty), has an extraterritorial dimension was a scant feature of decisions by international human rights enforcement modalities, and usually entirely absent from general academic discussions of international human rights law.

However, in the post-millennial, second-semi-centennial period of international human rights law, not only have certain extraterritorial actions associated with the 'War on Terror' and continuing outside that designation, involving human rights concerns-the US detention facility in Guantánamo Bay, Cuba, the Abu Grahib prison abuse scandal, extraordinary rendition, the practice of targeted killings by so-called 'drones'-brought the general topic of human rights and extraterritoriality to more general prominence. ${ }^{4}$ Also, there has been a considerable increase in decisions by judicial and quasi-judicial bodies affirming the position that human rights treaty law includes obligations relating to territorial acts and omissions by states that have an extraterritorial 'effect' on human rights, notably through a non-refoulement-type obligation (an obligation not to send someone back to another country when there is a risk of harm there) being 'read in' to treaties that do not contain an express stipulation of this kind, and also that human rights treaty obligations apply to states when they act extraterritorially. ${ }^{5}$ These decisions have ranged across all the global and regional human rights bodies that interpret human rights treaties, such as the United Nations Human Rights Committee when it comes to the International Covenant on Civil and Political Rights, and the Inter-American and European bodies interpreting their associated regional instruments. ${ }^{6}$ Such specialist jurisprudence has been complemented, in the case of extraterritorial applicability, by wide-ranging treatment by the generalist International Court of Justice. ${ }^{7}$ Building on earlier decisions, this jurisprudence has consolidated the treatment of extraterritoriality (extraterritorial 'effects' responsibility, and applicability extraterritorially) so that there is now a critical mass of canonical authority on this topic, as a matter of human rights treaty law, as was not the case at the turn of the century and the moment of the semi-centennial of international human rights law. 
These developments are significant for the topic of recognition/non-recognition because they potentially suggest a different source of applicable human rights standards to the standard approach of seeking to identifying such standards from within the customary international law framework: human rights treaty law. At the same time, the meaning and scope of the extraterritorial 'effects' based obligation, beyond its particular non-refoulement manifestation, and the extraterritorial applicability of human rights treaty law, are still considerably uncertain and underdeveloped, the aforementioned decisions on extraterritorial applicability, for example, mostly having addressed the topic piecemeal through considering particular situations involving direct state extraterritorial actions (e.g. military occupations). Hitherto, recognition/non-recognition has not been a case study considered through either the extraterritorial 'effects' obligation or the extraterritorial applicability frameworks. However, from the decisions it is possible to discern the contours of an albeit constantly shifting and expanding general framework (to be set out below) which can be considered as potentially operable in relation to any situation with extraterritorial implications, including the recognition/non-recognition of states and governments. Given this, the present chapter applies the general framework of human rights treaty obligations to the topic of recognition/non-recognition, explaining how this might operate and what it would require of states in their practice here were it to operate.

The chapter begins by explaining the general approach to the particular circumstances in which international human rights treaty obligations operate in relation to extraterritorial situations. It then considers how these circumstances might relate to the practice of recognition/non-recognition, thereby being potentially operable to it. The role of recognition of states and governments in international law is then explained. Following this, the chapter addresses what human rights treaty standards would require of recognition/non-recognition were they to be in operation. Finally, consideration is given to what account, if any, needs to be given to a divergence in the human right treaty obligations of the recognizing/non-recognizing state, and the obligations of the object of that recognition/non-recognition. 


\section{The territorial and extraterritorial application of human rights treaty obligations, and the 'effects' obligation in particular}

It is assumed that human rights treaty law applies to a state within its own territory. ${ }^{8}$ As mentioned, an extraterritorial 'effects'-based obligation operates in the context of transfers of individuals from state territory, in circumstances where such individuals face certain forms of human rights abuses in the place to which they are being transferred-a form of non-refoulement obligation. ${ }^{9}$ An express provision concerning non-refoulement is contained in the Torture Convention, and operates for individuals who meet the definition of a 'refugee' in the Refugee Convention. ${ }^{10}$ Such an obligation was established as something to be 'read in' to certain other human rights treaties not containing express provisions to this effect, through the interpretation of international human rights bodies, beginning with a decision by the European Court of Human Rights in 1989. ${ }^{11}$

Outside the particular context of transfers of individuals, there has also been a more general affirmation of the applicability of human rights law on the basis of extraterritorial 'effects', whereby 'responsibility can be involved because of acts' of state authorities 'producing effects outside their territory'. ${ }^{12}$ This is of potential relevance in a broader set of circumstances, yet to be clarified and determined in authoritative decisions. So far, the one area where clarification has been provided outside the context of the non-refoulement-type obligation is in connection with environmental damage, in relation to which in 2017 the Inter-American Court of Human Rights stated that there would be responsibility under Inter-American human rights instruments if there was a causal relationship between something happening within a state's territory and the human rights of people outside its territory. ${ }^{13}$

In addition to the uncertainty over what the scope of the term 'effects' is (including how the 'causal relationship' invoked by the Inter-American Court is defined), the scope of rights implicated in this area of responsibility is unclear. The nonrefoulement-type of obligation (covering one particular 'effect') is presently understood to relate only to a sub-set of core human rights, notably those which are non-derogable, i.e. incapable of any limitation. ${ }^{14}$ These include the prohibition 
of torture, inhuman and degrading treatment, the prohibition of racial discrimination, the prohibition on slavery, and the right not to have life arbitrarily deprived, which all exist as a matter of international human rights treaty law as well as in customary international law. ${ }^{15}$

As for the application of human rights law to a state acting extraterritorially, although some of the key states whose direct kinetic actions in extraterritorial contexts have important implications for human rights-Israel, Russia, the UK, the USA - refute the extraterritorial application of human rights treaty law, either in general or in relation to some, but not all, the treaties they are parties to, the universally-held position as a matter of all regional and global human rights interpretation bodies, and the International Court of Justice, as well as independent academic experts, is that human rights treaties do apply extraterritorially. ${ }^{16}$ The aforementioned consolidation of the international authority on this matter in the post-millennial period makes the refusenik position difficult to sustain credibly. What is subject to broader dispute and considerable uncertainty is the question of the extent of applicability.

This position is complex because human rights treaty provisions are not uniform when it comes to applicability in general, a matter that has implications for extraterritorial applicability. To summarize overall a very complex and varied position, the extraterritorial applicability of human rights treaty obligations operates in the following manner. ${ }^{17}$ The general prohibitions of racial and sex discrimination in the associated specialist Conventions apply extraterritorially in a generalized, free-standing sense. ${ }^{18}$ All other human rights treaty obligations apply to situations where a state exercises effective control over either territory or individuals, and/or if a state exercises effective authority and/or decisive influence over another state or non-state entity exercising territorial control. ${ }^{19}$ In addition, for socio-economic rights, there is a further obligation, designated as 'international co-operation', within which resource and technology transfers across borders are situated. ${ }^{20}$ The aforementioned 'effects'-based obligation can operate extraterritorially, at least in circumstances where a state exercises effective control in such a context. Here, a state bears an obligation relating to acts or omissions taking place within a zone of extraterritorial control exercised by that 
state, when these acts or omissions have an effect on the enjoyment of human rights extraterritorially outside that zone of control. ${ }^{21}$ The same uncertainty as to the potential content of this obligation, beyond a non-refoulement-type requirement, exists as in the case of its territorial manifestation.

These twin developments in human rights law-obligations regarding extraterritorial 'effects', notably in the context of the transfer of individuals, and extraterritorial applicability — have both developed by way of the interpretation of human rights treaties that did not contain express provisions clearly indicative of the position in this regard (apart from the express non-refoulement obligations in the Refugee and Torture Conventions). These interpretations reflect a teleological approach to the interpretation of human rights treaties as 'living instruments', where meanings change over time. As the changes in both areas have been in the direction of progressively expanding coverage, it can be speculated that there is the potential for further developments in the future that could encompass other extraterritorial effects outside the context of the transfer of individuals. This has already happened, with the aforementioned Advisory Opinion of the InterAmerican Court of Human Rights, in the context of environmental damage, and could therefore move further to encompass recognition and non-recognition.

\section{Applying human rights treaty law to recognition/non-recognition practice}

Bearing in mind the foregoing observations about the territorial and extraterritorial application of human rights treaty obligations, how might these obligations apply to acts of recognition and non/recognition?

As determinations that originate in government departments usually in state capitals, acts of recognition and non-recognition take place territorially. Clearly, then, they fall within the territorial scope of the state's human rights obligations in terms of the accepted regime of applicability. Moreover, the implementation of determinations on recognition/non-recognition will often have consequences for the state's own extraterritorial activities in its relations with other states, since the position taken on recognition/non-recognition will determine, for example, where 
and on what basis diplomatic premises are located, with whom and on what basis diplomats and other state officials such as military personnel meet with foreign officials, how decisions are made within intergovernmental organizations etc. At the very least, human rights law applies to states in their extraterritorial diplomatic premises and military facilities, as one of the most well-established accepted situations of extraterritorial applicability. ${ }^{22}$

\section{The role of recognition of states, governments, and state activities in international law}

Before addressing what these human rights norms might require of states in recognition/non-recognition practice, it is necessary to clarify certain key aspects of the normative framework concerning recognition of states and governments as a matter of general international law. ${ }^{23}$

In international law, the state is the legal person-the actor who is the bearer of rights and obligations. The government is the agent for that legal person-the representative of it, whose acts and omissions engage the state's legal responsibility. Changes of government usually have no bearing, legally, on the continued existence of the state. Recognition/non-recognition practice can thus be focused on the state itself (e.g. the decision to recognize/not recognize a secessionist entity as a distinct state and in consequence to recognize/not recognize that the territory covered by the entity is no longer part of the territory of the state within which it was located) or the particular government within a state (which is not a matter of whether or not the state the government purports to represent is or is not being recognized). Recognition/non-recognition can be focused on the existential claims made by the state the government: for the state, that it is a state; for the government, that it is the legitimate representative of the state. It can also be focused on the legitimacy of a particular activity performed by the government on behalf of the state, an associated claim, if any, about the basis for this, and the international legal implications of the activity and associated claim, for example when a state administers territory outside its sovereign territory (e.g. an occupation). 
International law prescribes criteria which must be met before an entity claiming new statehood can enjoy this status in law. ${ }^{24}$ These criteria are based on practical viability across the key attributes of statehood-whether there is a co-existing effective government, defined territory, and fixed population, and independence from external authority. In general, the recognition practice of other states to claims of statehood-whether they decide to recognize or not-recognize such claims - is regarded to be, legally, merely 'declaratory' not 'constitutive' of statehood-i.e. it does not have normative effect in and of itself. ${ }^{25}$ However, it can be 'constitutive' in certain circumstances in borderline cases where conformity to one or more of the aforementioned criteria is in question. ${ }^{26}$ Here, then, the recognition practice of states can have a material effect on whether or not a claimant entity can become a state as a matter of international law.

The general obligations that states bear to other states, to respect sovereignty and territorial integrity, requires them to 'recognize' other entities as states if such entities meet the legal criteria for statehood. This is a de minimis, essentially negative requirement concerned with non-intervention. States are not required to conduct diplomatic relations and/or recognize a particular government but they would be required to respect the state's territorial integrity and so its territorial borders. This would include, therefore, an obligation not to recognize that part of the territory of a state is somehow not its territory, if such a position would run counter to the position on the status of the territory as a matter of international law. This therefore has implications for recognition practice generally, for example if a state were to recognize as part of one state a territory that is actually legally part of the territory of another state.

\section{What human rights treaty law would require of recognition/non- recognition practice}

What, then, might human rights treaty law norms require of recognition/nonrecognition practice? This would all be in the category of the speculative scope of the 'effects' obligation beyond its non-refoulement-type manifestation, both territorially and extraterritorially. 
To consider what this might involve, it is necessary to review the general elements of human rights obligations. Here, the nature of what human rights obligations require in substance is complex and varied, both within and between different human rights treaties and also, because of different constellations of treaty accession and associated declarations and reservations by states, between states. In very general terms, states are obliged to 'respect,' 'protect' and 'fulfil' the human rights in these instruments. 'Respect' denotes a negative obligation, not to interfere negatively in the enjoyment of human rights. 'Protect' denotes an obligation to protect individuals and groups from interferences in the enjoyment of their rights by others. 'Fulfil' is again of a positive character, an obligation to secure the fulfilment of rights in a broader sense, notably in contexts where public provision is needed (e.g. in relation to socio economic rights).

Bearing in mind that the subject matter at issue is the human rights situation as far as the object of recognition/non-recognition is concerned, the starting point is to consider what role recognition/non-recognition by another state could potentially play - what 'effect' it might have-when it comes to this situation. In other words, if a state or claimant state fails to respect/protect/fulfil human rights, what implications might this have for the obligation other states have to respect/protect/fulfil rights through their recognition/non-recognition practice in relation to the first state?

When recognition is understood legally to play a constitutive role in a claim to statehood that would involve a violation of human rights law, there is a clear causal link between it and the violation in a direct sense, implicating the obligation to 'respect'. This would suggest, then, that when it comes to recognition that might be constitutive of a claimant entity's right to statehood, and the statehood in question would involve a violation of human rights law, then states would be prohibited as a matter of their human rights treaty obligations from the act of recognition. An example of this situation arising would be if an entity claiming statehood is constituted in a manner that involved a violation of the right to selfdetermination, which exists as common Article 1 to the two main human rights treaty Covenants, as well as existing in customary international law. ${ }^{27}$ 
Equally, even when recognition does not play a legally constitutive role in an arrangement that involves a violation of human rights, if the violation of human rights is inherent in that which is being recognized, the positive obligation to 'protect' would require the state to refuse recognition. This would therefore cover the aforementioned example of an entity claiming statehood which is constituted in a manner involving a violation of self-determination even in circumstances where recognition would not play a constitutive role, and also other scenarios, for example a state claiming to annex territory outside its own sovereign territory, in contravention of the right of self-determination of the people of that territory. In such a situation other states would be prohibited as a matter of their human rights treaty obligations (quite apart from any other relevant areas of international law) from recognizing the annexation.

Beyond the above two types of recognition to which human rights treaty law would oblige particular practices, are the much more common situations where a government that might be recognized or non-recognized is engaged in some form of human rights violations, but the violations are not directly bound up in those aspects of it which would be recognized were recognition to happen. For example, in the aforementioned example of a state purporting to annex land in violation of the right of self-determination of the people of that land, where the act of recognition at issue is not of the annexation itself but of the government's general claim to represent the state involved. In this context, there is no direct link between the act of recognition/non-recognition and the human rights violation in the same manner as the two earlier cases. Of course, recognition practice can be a means through which the human rights concerns could be addressed and, indeed, this practice could be used as leverage to address them. Equally, the recognition of a state and/or government involved in human rights abuses could be regarded as a tacit endorsement of/collusion with the abuses. However, what might be most effective in securing human rights in such circumstances is not straightforward. Non-recognition can act as an effective device to improve practice in some cases, and lead to a bunker-mentality and an increase in repression in others. Engagement can be seen as encouragement to continue business-as-usual, or be the basis for successful efforts to try to promote greater human rights compliance. 
What all of this suggests is that the particular activity at issue-recognition and non-recognition - is not of a nature that is amenable to a clear position when it comes to its effect on human rights compliance outside of the two areas reviewed above (in those two areas, its effect, and so the requirements of human rights law to it, is clear). The state's human rights obligations when it comes to diplomatic relations generally, including recognition and non-recognition, are best understood in these contexts as requiring best efforts determined by the particular situation at issue.

This is important in and of itself, because it moves the question of human rights promotion as a matter of diplomatic practice from an arena of discretion to one of obligation. But then what is required will vary in any given case, not necessarily tied (outside the two categories above) to a particular requirement of recognition or non-recognition.

What the present account of the extraterritorial meaning of human rights law suggests is that actually diplomatic relations is an arena where states are obliged to take action to promote human rights, not simply given the right to do so if they chose. For the present focus on recognition and non-recognition, this does, therefore, mean that human rights considerations are a mandatory not discretionary part of the law applicable to practice in this area. That said, bearing in mind the foregoing analysis, what they require in any given case is not straightforward matter when it comes to whether or not recognition is permissible. As mentioned, there are two areas where the implications for recognition practice are clear and uniform. Outside these areas, the obligation to secure rights through recognition practice continues - so an obligation, not just a right-but whether or not this requires non-recognition would fall to be determined in any given situation by considering recognition alongside the full range of diplomatic measures and considering what, in the round, and based on the context, a 'best efforts' test would require.

In addition, it is also necessary to consider the state's human rights obligations in the round, which brings in its obligations vis à vis the people of all other states, not 
just the particular state/claimant state that is the focus of an individual instance of recognition/non-recognition. And, of course, the rights of the people within its own territory. The implications for all these obligations in the round would have to be brought into the analysis when determining what the legal position would be in any given instance of recognition/non-recognition. Moreover, beyond human rights law, the state will also have other obligations in international law, which may also apply in a particular instance of recognition/non-recognition. The legal position the state would be arrived at by taking full account of all the applicable law, not just human rights law.

It might be said that this normative picture is far too complex, multi-layered and varied to be amenable as regulatory system that is capable of clear, meaningful, and consistent application.

Such a question asked in relation to the present topic is a particular instantiation of a broader challenge that operates in relation to the international legal system generally. A consideration of it is beyond the scope of this piece, implicating the general work that has been done on the question of normative complexity and overlaps. $^{28}$ But it is a challenge that has to be faced up to in relation to international law generally, not only the present topic of human rights and recognition in particular.

That said, there is one particular feature of human rights law that can be emphasised by way of illustrating one key element of how the challenge might be addressed. Certain core areas of human rights obligations are understood to have jus cogens 'trumping' status. ${ }^{29}$ This status denotes that they are incapable of limitation - the aforementioned non-derogability - and would prevail in the face of any conflicts with other legal obligations. A narrow sub-set of human rights obligations have such status, covering the foregoing list of non-derogable rights of a universal character (so not the prohibition of the death penalty), as well as the right of self-determination, core protections of individuals in humanitarian law (the laws of war), and the prohibition on racial discrimination in general and apartheid in particular. 
The characterization of these norms as having this status would be an important factor when considering in any given situation of recognition/non-recognition how the implications for particular rights have to be balanced against each other and how certain human rights obligations have to be balanced against other obligations in international law.

\section{How would obligations be linked to those of the recognized/non- recognized entity?}

It has already been observed that there is a wide variety of different constellations of acceptance of international human rights treaty obligations between states. It is commonplace, then, for any given state engaged in recognition practice to be subject to a different configuration of human rights obligations when compared to the position of the states and governments that are the object of its recognition practice. This situation of divergence is potentially acute in a situation when new states are being recognized and their position as far as being bound by human rights law is unclear/contested/to be determined. ${ }^{30}$

The foregoing analysis on the potential role of human rights law to recognition practice has referenced 'human rights abuse' and 'human rights violations' in terms that omitted to indicate 'according to whom.' Whereas the focus is on the object of recognition when it comes to the concerns/violations/abuse, the potential divergence between the substantive obligations of that state, and the recognizing state, raise the question as to which standards should be used to determine which violations the recognizing state then has a responsibility to be concerned with in its recognition practice.

It is important to distinguish between recognition/non-recognition on matters that directly implicate the rights and obligations of the recognized/non-recognized entity, and all other matters.

In the case of the former category, if the standards that were being adopted by the recognizing/non-recognizing state were not applicable to the object of this practice, then the adoption of the former would involve imposing them on the latter 
without its consent. This is 'imposition' in the sense that the latter's own rights and obligations are contingent on compliance with the standards in question. Such a situation would be the case if, for example, a state made compliance with nonlegally-universally-accepted human rights standards (e.g. the prohibition of the death penalty) a criterion for its acceptance of a claim to statehood of an entity that met the legal criteria for statehood.

In such instances, then, the role of human rights treaty law standards in recognition/non-recognition must be limited to those standards that are universally applicable or, at least, applicable in common as a matter of treaty law as between the recognizing/non-recognizing state and the object of this practice. The category of 'universally applicable' denotes standards in customary international law, and so would cover, at least, the aforementioned areas of human rights obligations regarded to have jus cogens status.

In the case of the latter category, recognition/non-recognition would not have a direct bearing on the legal rights and obligations of the object of the recognition/non-recognition. This would include, for example, the decision to recognize/not-recognize a particular government in a state. Given that, as mentioned above, there is no right on the part of a state to have its government recognized by other states, making such recognition contingent on compliance with human rights legal standards that are not applicable to that state would not involve imposition of those standards on the other state in the same way.

\section{Conclusion}

In ratifying international human rights treaties, states have accepted obligations which have potential implications for their recognition practice of other states and governments. These potential implications are derived from the existence of extraterritorial 'effects' based responsibility, and the operation of human rights treaty obligations both territorially and extraterritorially. Both these elements have come to be accepted interpretations of human rights law, and suggest the potential for further interpretative developments that would encompass obligations relative to recognition/non-recognition as part of them. 
${ }^{1}$ On customary international law, see e.g. B S Chimni, 'Customary International Law: A Third World Perspective' 112 AJIL 2018), and sources cited therein. On the law of statehood, see J Crawford, The Creation of States in International Law, 2nd ed. (OUP, 2007) (Crawford 2007). On the law of recognition of statehood and governments, see the sources cited in the 'Oxford Bibliographies' entry on the subject here: http://www.oxfordbibliographies.com/view/document/obo9780199796953/obo-9780199796953-0009.xml.

${ }^{2}$ For a discussion of standards of governance and recognition practice, and the implications for international law, see e.g. B R Roth, Governmental Illegitimacy in International Law (Oxford University Press) 1999). This subject is also covered by other sources in the 'Oxford Bibliographies' entry cited above, note 1.

${ }^{3}$ On this, see e.g. R Wilde, 'Dilemmas in Promoting Global Economic Justice through Human Rights Law', in N Bhuta (ed), The Frontiers of Human Rights (OUP, 2016), ch 5 (Wilde 2016) (on socioeconomic rights), $\mathrm{R}$ Wilde, 'The extraterritorial ap plication of international human rights law on civil and political rights', in S Sheeran and S N Rodley (eds), Routledge Handbook of International Human Rights Law (Routledge, 2013), ch 35 (Wilde 2013a) (on civil and political rights) R Wilde, 'Legal Black Hole - Extraterritorial State Action and International Treaty Law on Civil and Political Rights' 26 (2005) MJIL 739 (Wilde 2005) (also on civil and political rights); R Wilde, 'Human Rights Beyond Borders at the World Court: The Significance of the International Court of Justice's Jurisprudence on the Extraterritorial Application of International Human Rights Law Treaties' 12 (2013) CJIL 639 (Wilde 2013b), and sources cited therein.

${ }^{4}$ See e.g. Wilde 2005 (above note 3 ) and sources cited therein.

${ }^{5}$ An express non-refoulement obligation exists in the Convention Relating to the Status of Refugees, Geneva, 28 July 1951, entry into force 22 April 1954, 189 UNTS 137, <http://www.unhcr.org/3b66c2aa10.html> (Refugee Convention 1951), Art. 33; Convention against Torture and Other Cruel, Inhuman or Degrading Treatment or Punishment, New York, 10 December 1984, entry into force 26 June 1987, 1465 UNTS 85, http://www.ohchr.org/EN/Professionallnterest/Pages/CAT.aspx (CAT 1984), Art. 3. For the 'reading in' of a somewhat equivalent obligation to treaties that do not contain an express stipulation, see Soering v. the United Kingdom, European Court of Human Rights, 161 Eur. Ct. H.R. Series A (1989), [obtainable from www.echr.coe.int], 07 July 1989 and, more generally, J McAdam, Complementary Protection in International Refugee Law (OUP, 2007) (McAdam 2007), Chapters 3 and 4 . On the applicability of human rights treaty law to extraterritorial action, see the reviews in the sources cited above in note 3.

${ }^{6}$ See the sources cited id.

${ }^{7}$ See Wilde 2013b (above note 3).

8 That said, the nature of obligations when applicable are different if a state does not exercise effective control over all of its territory. See the discussion in Wilde 2013a (above note 3), Section 3.6, and sources cited therein.

${ }^{9}$ See the sources cited above note 5 .

${ }^{10}$ See the sources cited above note 5 . 
${ }^{11}$ The Soering decision, cited above note 5.

12 See Drozd and Janousek v France and Spain, Appl. 12747/87, ECtHR, 26 June 1992, Series A, No. 240, http://hudoc.echr.coe.int/eng?i=001-57774 (Drozd and Janousek 1992), para. 91, and A/Skeini and Others v United Kingdom, Appl. 55721/07, ECtHR, Grand Chamber, 7 July 2011, (2011) RD 1093, (2011) 53 EHRR 18, http://hudoc.echr.coe.int/eng?i=001-105606 (A/-SkeiniECHR 2011), paras. 131, 133.

13 The Environment and Human Rights (State Obligations in Relation to the Environment in the Context of the Protection and Guarantee of the Rights to Life and to Personal Integrity Interpretation and Scope of Articles 4(1) and 5(1) of the American Convention on Human Rights), Advisory Opinion OC-23/18, IACHR, 15 November 2017, (ser. A) No. 23, http://www.corteidh.or.cr/docs/opiniones/seriea_23_esp.pdf (Environment and Human Rights IACHR 2017)

${ }^{14}$ On the scope of the non-refoulement-type obligation, see the sources cited above, note 5 .

${ }^{15}$ See the following derogation provisions: European Convention for the Protection of Human Rights and Fundamental Freedoms, Rome, 4 November 1950, entry into force 3 September 1953, ETS 5, 213 UNTS 221, https://www.coe.int/en/web/conventions/full-list/-/conventions/treaty/005 (ECHR 1950), Art 15; International Covenant on Civil and Political Rights, New York, 16 December 1966, entry into force on 23 March 1976, 999 UNTS 171, http://www.ohchr.org/en/professionalinterest/pages/ccpr.aspx (ICCPR 1966), Art. 4; American Convention on Human Rights, San Jose, 22 November 1969, entry into force 18 July 1978, 1144 UNTS 123, https://treaties.un.org/doc/Publication/UNTS/Volume\%201144/volume-1144-I17955-English.pdf (ACHR 1969), Art. 27.

${ }^{16}$ For an example of the refusenik position, of the US, see the discussion in M J Dennis, 'Application of Human Rights Treaties Extraterritorially in Times of Armed Conflict and Military Occupation' 99 (2005) AJIL (Dennis 2005) and Wilde 2005, above note 3, Section IV.B. For the contrary authorities, see the reviews in the sources cited above note 3 .

${ }^{17}$ See in general the sources cited above note 3 , and the authorities referred to therein.

${ }^{18}$ See in Wilde 2013a (above note 3), Section 4.

${ }^{19}$ See the discussion in in Wilde 2013a (above note 3), Sections 3.3-3.5.

${ }^{20}$ See the discussion in Wilde 2016, above note 3, Section 7.

${ }^{21}$ Al-Saadoon and Mufdhi v United Kingdom, Appl. 61498/08, ECtHR, 2 March 2010, DR 2010-II, 61, http://hudoc.echr.coe.int/eng?i=001-97575 (A/-Saadoon ECHR 2010)

${ }^{22}$ See e.g. VM. v Denmark, App. No. 17392/90, 15 EHRR CD28, European Commission of Human Rights, 1993) (on diplomatic premises) and A/-Saadoon ECHR 2010, above note 21 (on military bases).

${ }^{23}$ See the sources cited above, note 1.

${ }^{24}$ See generally J Crawford, The Creation of States in International Law, 2nd ed. (OUP, 2007) (Crawford 2007)

${ }^{25}$ See the sources cited above, note 1.

${ }^{26}$ Id. 
${ }^{27}$ See ICCPR 1966, above note 16, Art 1; International Covenant on Economic, Social and Cultural Rights, New York, 16 December 1966, entry into force 3 January 1976, 993 UNTS 3, http://www.ohchr.org/EN/Professionallnterest/Pages/CESCR.aspx (ICESCR 1966), Art. 1. On self-determination, see the sources cited in the following Oxford bibliographies entry: http://www.oxfordbibliographies.com/view/document/obo-9780199796953/obo-97801997969530033.xml

${ }^{28}$ See the work by international lawyers through the rubric of 'fragmentation', e.g. Fragmentation of International Law: Difficulties Arising from the Diversification and Expansion of International Law, Study Group of the International Law Commission (finalized by Martti Koskenniemi), 13 April 2006, U.N. Doc. A/CN.4/L.682 (ILC Fragmentation 2006).

${ }^{29}$ See the Oxford Bibliographies entry, http://www.oxfordbibliographies.com/view/document/obo9780199796953/obo-9780199796953-0124.xml, and Encyclopedia of Public International Law entry, http://opil.ouplaw.com/view/10.1093/law:epil/9780199231690/law-9780199231690e1437?prd=EPIL, and sources cited therein.

${ }^{30}$ For a discussion of the human rights obligations of non-state territorial entities through the case study of Somaliland, see M Schoiswohl, Status and (Human Rights) Obligations of Non-recognized De Facto Regimes in International Law: The Case of "Somaliland"; The Resurrection of Somaliland against All International "Odds"; State Collapse, Secession, Non-recognition, and Human Rights (Martinus Nijhoff) 2004) 